\title{
Lambda Transducing Phage and Clones Carrying Genes of the cysJIHDC Gene Cluster of Escherichia coli K12
}

\author{
By CHERYL L. HUNT, V. COLLESS, M. T. SMITH, D. O. MOLASKY, \\ M. S. MALO AND R. E. LOUGHLIN* \\ Department of Biochemistry, University of Sydney, Sydney, New South Wales 2006, Australia
}

(Received 13 March 1987; revised 17 May 1987)

\begin{abstract}
DNA from each of two specialized transducing $\lambda$ phage, $\lambda \mathrm{d} c y s J I H D$ and $\lambda c y s J$, has been analysed by heteroduplex mapping. The segment of the Escherichia coli chromosome carried by $\lambda \mathrm{d} c y s J I H D$ was shown to be large, approximately $18 \mathrm{~kb}$ in length, and to replace a large length of $\lambda$ DNA, approximately $11 \mathrm{~kb}$, which includes the genes for integration and recombination. Thus $\lambda \mathrm{d} c y s J I H D$ is a bio-type transducing phage. $\lambda c y s J$ was shown to have lost very little $\lambda$ DNA and to carry about $8 \mathrm{~kb}$ of bacterial DNA. Sites for several restriction endonucleases were mapped in the DNA from each phage and cloning experiments located some of the genes of the cluster in relation to the restriction map. Cysteine regulation of the cloned cys $J$ and $c y s D$ genes was shown as well as cysteine regulation of $\beta$-galactosidase in some constructs. The direction of transcription of the cys $D$ gene was established, and from physical evidence the size of the "silent section' between the cysH and cys $D$ genes was estimated to be at least $11 \mathrm{~kb}$.
\end{abstract}

\section{INTRODUCTION}

The pathway of cysteine biosynthesis in Escherichia coli K12 and Salmonella typhimurium consists of two converging branches. In the sulphur branch, sulphate is ultimately reduced to sulphide and in the carbon branch, serine is acetylated to form $O$-acetylserine. In the final step, $O$-acetylserine reacts with sulphide to form cysteine (Trudinger \& Loughlin, 1981; Umbarger, 1978; Siegel, 1975). The structural genes for the enzymes of cysteine biosynthesis are located in different regions around the chromosome. The genes for the sulphur branch enzymes form a cluster at $59 \mathrm{~min}$ in the E. coli linkage map (Bachmann, 1983) and at $60 \mathrm{~min}$ in the linkage map of S. typhimurium (Sanderson \& Roth, 1983). Jones-Mortimer (1973) has shown that the orientation and gene order of this cluster in $E$. coli is: lys $A$ thy $A \arg A$ cysJIHDC. Studies of nonsense and deletion mutants of $S$. typhimurium have shown that three genes of this cluster, cysJ, cysI and $c y s H$, form an operon which is transcribed from the $c y s J$ gene end and that genes $c y s D$ and $c y s C$ do not form part of this operon (Loughlin, 1975, 1976).

A $\lambda$ specialized transducing bacteriophage, $\lambda \mathrm{d}$ cys $J I H D$, carrying most of this cluster has been shown to be denser than $\lambda$ in a $\mathrm{CsCl}$ gradient and to be a defective phage. DNA from this phage had been used to study the synthesis of cysteine messenger RNA (Fimmel \& Loughlin, 1977). In order to study the cluster further, we have isolated additional deletion mutants and transducing phage. Here we report the map order of the end points of deletion mutants and transducing phage and characterization of $\lambda \mathrm{d} c y s J I H D$ and another phage $(\lambda c y s J)$ by heteroduplex and restriction endonuclease analysis. The location of some genes by cloning various fragments of the cluster is also described.

\section{METHODS}

Bacterial strains and vectors. The strains used were derived from E. coli $\mathrm{K} 12$ and are listed in Table 1. Plasmids used for cloning were pBR322 (Sutcliffe, 1979), pLG400 (Guarente et al., 1980) and pMC1403 (Casadaban et al., 1980). 
Table 1. E. coli K12 strains

The following strains have been described by Fimmel \& Loughlin (1977): CSH45, JM57, JM81A, JM221, RL144, RL145, RL149, RL155, X7150.

Strain

C600K
KB9163
MC4100

NK5031
RL75

RL76 and RL77

RL147

RL157

RL198

RL363

RL364

RL365

RL367

RL405

RL406

RL417

RL421

RL428

RL432

RL439

RL440

RL441

RL500

RL502

RL622

RL641

RR1
Genotype

$$
\text { galK* }
$$

HfrKL16 thi nalA $900 \dagger$

$\mathrm{F}^{-}$araD139 $\Delta($ argF-lac) U169 rpsL150 relAI flbB5301 deoCl ptsF 25 rbsR

lac Z $\mathrm{m} 5265 \ddagger$

HfrKL16 thi nalA900 (גc1857 Sam7 xisam6 b519 b515 nin 5$) \dagger \S$

\section{As for RL75}

$\mathrm{HfrH} \Lambda(\operatorname{cys} J I H) s t r^{\mathrm{s}} \lambda^{\mathrm{s}} \dagger$

$\mathrm{HfrH} \sup \Lambda($ cysJIH $)(\lambda c I 857$ Sam 7$)(\lambda \mathrm{d} c y s J I H) \dagger$

$\mathrm{F}^{-} \operatorname{cys} J(\lambda \mathrm{c} 1857 \mathrm{Sam} 7)$

cysJ [pRL5]*

lac Z^m5265 [pRL6]+

cys $J[\mathrm{pRL} \text { ] }]^{*}$

cys $J$ [pRL9]*

$\mathrm{F}^{-} \operatorname{cys} J(\lambda c I 857 \operatorname{Sam} 7)(\lambda c y s J I)$

$\mathrm{F}^{-} \operatorname{cys} J(\lambda c I 857 \operatorname{Sam} 7)(\lambda c y s J) \|$

HfrKLI6 nalA900 thi $\Delta($ cysJ)†

cys $J^{*}$ ?

cys $J^{* *+\dagger}$

cys $D^{* *} \ddagger \ddagger$

cys $J[\mathrm{pRL}$ 98]**

cysJ [pRL99]**

cysJ [pRL100]**

cysJ [pRL1]*

cysJ [pRL3]*

cys $D$ [pRL5]**

lacZ $\triangle m 5265$ [pRL81]†
Source or derivation

N. S. Willetts

K. D. Brown

Casadaban (1976); See also

Silhavy et al. (1984)

G. Zurawski

Fimmel \& Loughlin (1977)

This work

Fimmel \& Loughlin (1977)

A. L. Fimmel

RL144 lysogenized by

$\lambda$ cI857 Sam7

This work

This work

This work

This work

This work

This work

This work

This work

This work

This work

This work

This work

This work

This work

This work

This work §§

This work

G. Zurawski

* Other markers F- thr-1 leu-6 thi-1 supE44 lacYI tonA2l $\lambda^{-}$.

† Other markers $\Delta\left(\right.$ gal-att ${ }^{\lambda}-$ bio-uvrB $)$.

$\ddagger$ Other markers $\mathrm{F}^{-}$suIII' $\mathrm{nal}^{\mathbf{R}}$.

$\S$ Prophage integrated near the cysJ gene.

Other markers: thr-1 leu-6 trp-1 his-1 arg Hl thi-1 xyl-7 ara-13 mtl-2 gal-6 lac YI str-9 tonA2 supE.

If Derived from strain $\mathrm{C} 600$ by selection of $\mathrm{Thy}^{-}$using trimethoprim, then the $\arg A$ marker was brought in from

JM221 by P1 cotransduction, then the cysJ mutation brought in by P1 cotransduction from strain RL144.

** Other markers proA2 leuB6 thi-l lac YI hsdR hsdM supE44 $\lambda^{-}$trpR55 ara-14 galK2 rpsL20 xyl-5.

$\dagger+$ Derived from strain RRl by the route described for strain RL421.

$+\ddagger$ Derived from strain RR 1 by the route described for strain RL421 except that the cys $D$ mutation was brought

in from strain RL148 (an $\mathrm{Arg}^{+}$derivative of $\mathrm{JM} 221$ ) by Pl cotransduction.

$\S \S$ Derived by transforming pRL5, obtained from strain RL363, into strain RL432.

Strain constructions and tests of lysates. Secondary site lysogens were isolated by lysogenization of strain KB9163 ( $\triangle a t t \lambda)$ with $\lambda$ cl857 Sam7 xisam6 b519 b515 nins by the method of Shimada et al. (1972). Independent lysogens were grown at $30^{\circ} \mathrm{C}$ in $\mathrm{L}$ broth and samples plated onto tryptone agar and incubated at $42{ }^{\circ} \mathrm{C}$ overnight. Temperature-resistant survivors were replica plated onto minimal agar to screen for the Cys ${ }^{-}$phenotype. Lysogens giving $\mathrm{Cys}^{-}$derivatives were used to prepare lysates by heat induction. These were tested for the ability to transduce a cys $J$ strain (RL144) to Cys ${ }^{+}$. Lysogens yielding such transductants thus had the prophage integrated near the cysJ gene.

Media and methods used for the isolation of deletion mutants and transducing phage have been described previously as have HFT (high frequency transduction) tests (Fimmel \& Loughlin, 1977). The following methods were the same as those used previously except for the minor modifications mentioned. For phage assays, the host strain X7150 was grown in tryptone broth supplemented with maltose to $1 \%(\mathrm{w} / \mathrm{v})$ and tryptophan to $40 \mu \mathrm{g} \mathrm{ml}^{-1}$. 
For transduction assays, recipient strains were grown in Kmal medium (Steege \& Low, 1975). Phage lysates were prepared as before except that induced cells were harvested and resuspended in SM buffer (Miller, 1972) prior to lysis with chloroform. The method used for the preparation of $\lambda$ c1857 Sam 7 xisam6 b519 b515 nin 5 has been described by Ingle \& Loughlin (1980).

Cross streaking tests. Recipient strains to be tested were patched to minimal plates supplemented with maltose to $0.2 \%$. After growth of these patches, $0.05 \mathrm{ml}$ donor lysate was streaked along a line across the width of a selection plate supplemented for control and test transductants. Cells of the test strains were streaked in a single movement along a line from top to bottom of the selection plate at right angles to the lysate line. Starved cells (Gottesman \& Yarmolinsky, 1968) of RL144 served as the control recipient strain and were similarly cross streaked near each end of the lysate line. Recipient strains giving no growth above and growth below the lysate line were considered to be transduced by phage in the lysate.

PI transductions. These were performed by the method of Miller (1972) except that adsorption mixtures comprised a total volume of $0.4 \mathrm{ml}$ and $0.4 \mathrm{ml}$ of $1 \mathrm{M}$-sodium citrate was added to the adsorption mixes prior to plating with $2.5 \mathrm{ml}$ of $\mathrm{F}$ top agar (Miller, 1972).

Preparation of phage DNA. The methods used for phage purification and extraction of DNA have been reported by Fimmel \& Loughlin (1977).

Heteroduplex analysis. Heteroduplex preparations were carried out using the formamide technique of Davis et al. (1971) and Davis \& Parkinson (1971) as modified by G. D. Clark-Walker (personal communication). Analytical grade formamide for hypophase solutions was obtained from Ajax Chemicals or BDH. For hyperphase solutions the formamide was obtained from Mallinckrodt and cytochrome $c$ from Sigma. Electron microscope copper grids (400 square mesh, $3.05 \mathrm{~mm}$ diam., from Polaron Equipment) were coated with Parlodion (Mallinckrodt) using redistilled n-amyl acetate (Polysciences). After picking up the DNA, the grids were rinsed with redistilled isopentane and shadowed with platinum/palladium $(80: 200.2 \mathrm{~mm}$ diam. wire from Polysciences mounted on $1.0 \mathrm{~mm}$ diam. tungsten wire from Wright) then rotated through $90^{\circ}$ and shadowed again. The grids were then viewed in a Philips $201 \mathrm{C}$ electron microscope at an accelerating voltage of $60 \mathrm{kV}$ with a condenser aperture of $30 \mu \mathrm{m}$. Photographs were taken at magnifications of $7000 \times$ and $20000 \times$. Photographic prints of heteroduplex DNA molecules were measured with a Talos digitizer linked to a Data General Eclipse $230 \mathrm{Z}$ computer or with a Leitz A.S.M. Semiautomatic Image Analyser.

Recombinant DNA techniques. Restriction endonucleases were obtained from Amersham, BRL, Boehringer Mannheim or New England Biolabs and used in accordance with the supplier's recommendations or with the buffers described by Maniatis et al. (1982). Digestion mixtures were incubated for $60-120 \mathrm{~min}$ at $37^{\circ} \mathrm{C}$ for complete digestion. Partial digestion was achieved either by using insufficient enzyme or by incubating for shorter periods of time or by a combination of these conditions. Double digests were achieved by cleaving complete digests, described above, with a second restriction endonuclease. The buffer salt concentration was adjusted, if necessary, to suit the second enzyme and digestion mixtures were then incubated for a further 60-120 min. Reactions were stopped by the addition of a solution containing $4 \mathrm{M}-\mathrm{urea}, 50 \%(\mathrm{w} / \mathrm{v})$ sucrose, $50 \mathrm{mM}-\mathrm{EDT} A$ and $0 \cdot 1 \%$ bromophenol blue.

The DNA fragments were separated by electrophoresis in $0.7 \%$ agarose (Sigma, low electroendosmosis) slab gels, $3 \mathrm{~mm}$ thick, in a horizontal apparatus (model 800, Aquebogue Machine and Repair Shop) in $36 \mathrm{~mm}$ Tris/30 mM-sodium phosphate buffer, $\mathrm{pH} 7 \cdot 5$, containing $10 \mathrm{~mm}$-EDTA. Electrophoresis was done at a voltage gradient of $1.5-2 \mathrm{~V} \mathrm{~cm}^{-1}$ with the gel submerged in the buffer. The gels were stained with ethidium bromide $\left(2 \mu \mathrm{g} \mathrm{ml}^{-1}\right)$ for $30 \mathrm{~min}$. The bands were visualized by illumination with a short wavelength transilluminator (model C61, UV Products) and photographed using Polaroid type 55 film or Kodak Tri-X Pan Professional film and a Kodak red filter.

Plasmid DNA was purified by the method of Selker et al. (1977). T4 DNA ligase was obtained from Boehringer Mannheim and used according to the supplier's recommendation. Transformation of cells was done using the procedures of Cohen et al. (1972) and Davis et al. (1980).

Plasmid constructions. Details of these are given in Table 2.

Enzyme assays. Cultures, grown usually overnight at $37^{\circ} \mathrm{C}$ in minimal medium with djenkolic acid $(0.42 \mathrm{~mm})$ or cystine $(0.42 \mathrm{~mm})$ as sole sulphur source, were inoculated into the same medium and grown at $37^{\circ} \mathrm{C}$. Cells were usually harvested in late exponential phase.

For NADPH-cytochrome $c$ reductase assays, cells were resuspended in $0.1 \mathrm{M}$-potassium phosphate buffer $\mathrm{pH} 7 \cdot 7$, containing $1 \mathrm{~mm}-\mathrm{EDTA}$, sonicated and the debris removed by centrifugation. Assays were done as described by Loughlin (1975). For ATP sulphurylase assays, frozen cells were disrupted in a modified Hughes press and the preparations mixed with $0.1 \mathrm{M}$-potassium phosphate buffer $\mathrm{pH} 7 \cdot 7$, containing 1 mM-EDTA, and debris removed by centrifugation. ATP sulphurylase assays were done by the method of Kredich (1971) with an extract of strain JM221 (cysD) as a source of adenosine phosphosulphate kinase and using phenol sulphokinase prepared from rabbit liver by method 1 of Gregory (1962).

For $\beta$-galactosidase assays, culture samples were toluenized and assays done as described by Miller (1972). Soluble protein in cell-free extracts was measured by the method of Lowry. 
Table 2. Fragments, vectors and host strains used in plasmid constructions

\begin{tabular}{|c|c|c|c|c|c|}
\hline \multirow[b]{2}{*}{ Plasmid } & \multicolumn{3}{|c|}{ Fragment cloned } & \multirow[b]{2}{*}{$\begin{array}{l}\text { Vector } \\
\text { used* }\end{array}$} & \multirow{2}{*}{$\begin{array}{c}\text { Host strain } \\
\text { used in } \\
\text { transformation } \dagger\end{array}$} \\
\hline & Source & Ends & $\begin{array}{l}\text { Size } \\
(\mathrm{kb})\end{array}$ & & \\
\hline $\mathrm{pRLl}$ & $\lambda c y s J$ & HindIII-BamHI & $11 \cdot 9$ & pBR322 & RL421 \\
\hline pRL3 & $\mathrm{pRLI}$ & HindIII-Sa II & 8.95 & pBR322 & RL421 \\
\hline pRL5 & $\lambda \mathrm{d} c y s J I H D$ & $B g l \mathrm{II}-B g / \mathrm{II}$ & $5 \cdot 43$ & pMC1403 & RL421 \\
\hline pRL6 & $\lambda \mathrm{d} c y s J I H D$ & BamHI-BamHI & $3 \cdot 80$ & pLG400 & NK 5031 \\
\hline pRL7 & $\lambda \mathrm{d} c y s J I H D$ & SmaI-SmaI & 4.45 & pMC1403 & RL421 \\
\hline pRL9 & $\lambda \mathrm{d} c y s J I H D$ & SmaI-SmaI & $7 \cdot 55$ & pMC1403 & RL421 \\
\hline pRL81 & $\lambda \mathrm{d} c y s J I H D$ & HindIII-HindIII & $7 \cdot 47$ & pLG400 & NK5031 \\
\hline pRL98 & pRL9 & $B a m \mathrm{HI}-B g l \mathrm{II}$ & $4 \cdot 21$ & pBR322 & RL428 \\
\hline pRL99 & pRL9 & SphI-HindIII & $4 \cdot 13$ & pBR322 & RL428 \\
\hline pRL100 & pRL9 & $S p h \mathrm{I}-B g / \mathrm{II}$ & 1.63 & pBR322 & RL428 \\
\hline
\end{tabular}

\footnotetext{
* For each construction the vector was digested with the same enzyme(s) used for the cloned fragment except that $B a m H I$ was used instead of $B g / I I$ in digesting the vector for the constructions of pRL5, pRL98 and pRL100.

$\dagger$ For pRL1 and pRL3 Ap ${ }^{R}$, Cys $^{+}$colonies were selected. For pRL98, pRL99 and pRL100, selection was for Ap ${ }^{R}$ and $\mathrm{Cys}^{+}$colonies were detected after replica plating. For pRL5, pRL6, pRL7 and pRL9, selection was for $\mathrm{Ap}^{R}$ on plates containing djenkolic acid and Xgal (5-bromo-4-chloro-3-indolyl $\beta$-D-galactopyranoside). Blue colonies were chosen for further analysis.
}

\section{RESULTS}

\section{Integration of $\lambda$ near cys $J$}

Two secondary site lysogens, strains RL76 and RL77, were isolated by lysogenization of KB9163 with $\lambda$ cI857 Sam 7 xisam6 b519 b515 nin5. Both were shown to have the $\lambda$ prophage integrated near the cys $J$ gene by the isolation of transducing phage carrying genes from this region of the chromosome (see Methods).

\section{Transducing phage}

Lysates prepared from the secondary site lysogens were used to transduce a lysogen with a cys $J$ point mutation (strain RL198) to Cys ${ }^{+}$. Transductant colonies were purified and screened by HFT tests (see Methods) using cysJ (RL144) and cysI (JM57) mutant recipients. Patches giving transductants with the $c y s J$ mutant but few or no transductants with the $c y s I$ mutant were used to prepare lysates which were assayed for their ability to transduce RL144 (cysJ), JM57 (cysI) and, for some, RL145 (cysH) to Cys ${ }^{+}$.

Three lysates transduced RL144 (cysJ) but not JM57 (cysI) to Cys ${ }^{+}$. One of the three strains yielding these lysates was selected for futher study. This strain was designated RL406 and the transducing phage, which originated from RL76, was designated $\lambda$ cysJ. Several lysates transduced JM57 (cysI) but not RL145 (cysH) to Cys ${ }^{+}$. A strain giving one of these lysates was designated RL405 and the transducing phage, derived from RL77, was designated $\lambda c y s J I$.

\section{Deletion mutants}

Survivors of temperature induction at $42{ }^{\circ} \mathrm{C}$ of strain RL75 were screened for $\mathrm{Cys}^{-}$derivatives by replica plating. $\mathrm{Cys}^{-}$colonies were purified and used in cross streaking tests with a lysate containing $\lambda c y s J$. Four strains were selected which yielded transductants in these cross streaking tests and transduction assays with $\lambda c y s J$ confirmed this result. All four strains could be transduced to $\mathrm{Cys}^{+}$by $\mathrm{Pl}$ grown on RL144 as donor. One strain was selected and designated RL417.

Combination of the above results with the positions of the end points of $\lambda \mathrm{d} c y s J I H D, \lambda \mathrm{d} c y s J I H$ and strain RL147 (Fimmel \& Loughlin, 1977) and the order of genes in the cluster (JonesMortimer, 1973) enabled the establishment of the order of end points and mutations across the cluster (Fig. 1). 


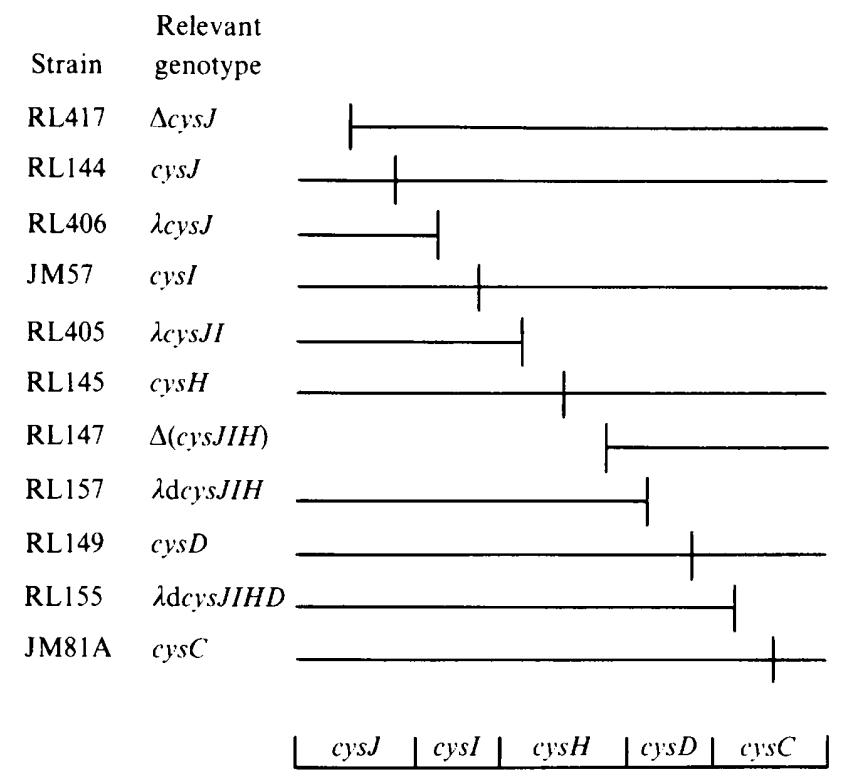

Fig. 1. Schematic diagram of the map order of point mutations and end points of deletion mutants and transducing phage. Horizontal lines represent DNA of the cluster present on transducing phage or in deletion mutants. Short vertical lines represent point mutations or the end points of deletions or bacterial DNA carried by the transducing phage. The last line represents the approximate positions of the genes of the cluster. These are not drawn to scale nor is the 'silent section' depicted (see Discussion). Due to this 'silent section', the novel joint of $\lambda \mathrm{d} c y s J I H$ may be located to the left of the novel joint of the deletion in strain RL147 [ $\Lambda(c y s J I H)]$.

\section{Heteroduplex analysis}

Heteroduplex molecules formed between $\lambda \mathrm{d}$ cysJIHD DNA, prepared from strain RL155, and $\lambda c$ I857 Sam7 DNA, from strain CSH45, showed two deletion loops and one large substitution loop. Their structure is shown schematically in Fig. 2(a). The two deletion loops correspond in position to the $b 519$ and $b 515$ deletions present in the $b$ region of the parent of the transducing phage ( $\lambda$ c 1857 Sam 7 xisam6 $b 519$ b515 nin 5). Thus the $b$ region has not been lost in the formation of $\lambda \mathrm{d} c y s J I H D$ and as the substitution loop is large, the phage DNA lost must correspond to the genes for recombination to the right of the attachment site (Szybalski \& Szybalski, 1979). Thus $\lambda \mathrm{d} c y s J I H D$ is a bio-type transducing phage. No evidence was found for a deletion loop due to the nins deletion of the parent of $\lambda \mathrm{d} c y s J I H D$.

The length of $\mathrm{H}$ given in Fig. 2(a) was calculated using the double stranded length to the left of the attachment site $(\mathrm{A}+\mathrm{C}+\mathrm{E})$ as an internal standard (Davis et al., 1971; Davis \& Parkinson, 1971 ; Lis \& Schleif, 1975). The value of $22.5 \mathrm{~kb}$ for this length was derived from a value of $48.502 \mathrm{~kb}$ for $\lambda$ DNA and the known locations of the attachment site (Sanger et al., 1982) and the b519 and b515 deletions (Szybalski \& Szybalski, 1979). The ratio of the double stranded region to the right of the attachment site $(\mathrm{H})$ to the internal standard $(\mathrm{A}+\mathrm{C}+\mathrm{E})$ was 0.44 , corresponding to a value of $9.9 \mathrm{~kb}$ for the size of $\mathrm{H}$. Of the two single stranded arms of the substitution loop, the longer $(\mathrm{G})$ must correspond to bacterial DNA and the shorter $(\mathrm{F})$ to $\lambda \mathrm{DNA}$, as $\lambda \mathrm{d} c y s J I H D$ has a greater density than $\lambda$ (Fimmel \& Loughlin, 1977). Thus the shorter single stranded $\lambda$ DNA of the substitution loop $(\mathrm{F})$ is $10.9 \mathrm{~kb}$ and was used as a single stranded standard to measure the single stranded bacterial DNA $(G)$ of the substitution loop, giving a value of about $18 \mathrm{~kb}$.

A schematic representation of the heteroduplex molecules formed between $\lambda c y s J$ DNA and $\lambda c 1857 \mathrm{Sam} 7 \mathrm{DNA}$ is shown in Fig. 2(b). Of the three loops evident, two correspond to deletion loops due to the $b 519$ and $b 515$ deletions. The third loop is more likely to be an insertion loop due to the bacterial DNA carried by $\lambda c y s J$ rather than a substitution loop as the length 
(a)

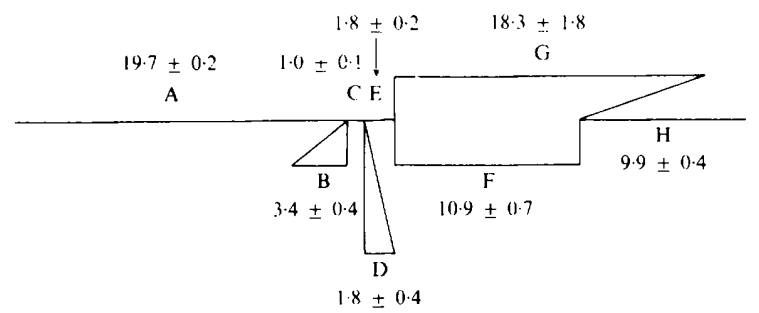

(b)

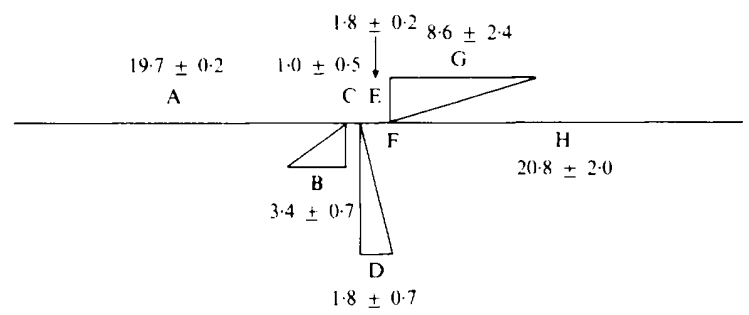

Fig. 2. Schematic diagram of heteroduplex molecules formed between $\lambda c 1857$ Sam7 DNA and $\lambda \mathrm{d} c y s J I H D(a)$ or $\lambda c y s J(b)$ DNA. The mean values and standard deviations are calculated from 11 measured molecules for $\lambda \mathrm{dcys} J I H D$ and 20 measured molecules for $\lambda c y s J$ and are given in $\mathrm{kb}$.

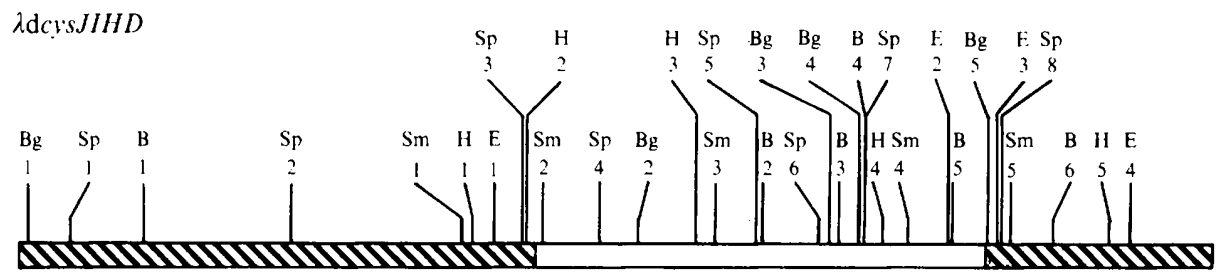

cys $J I H D$
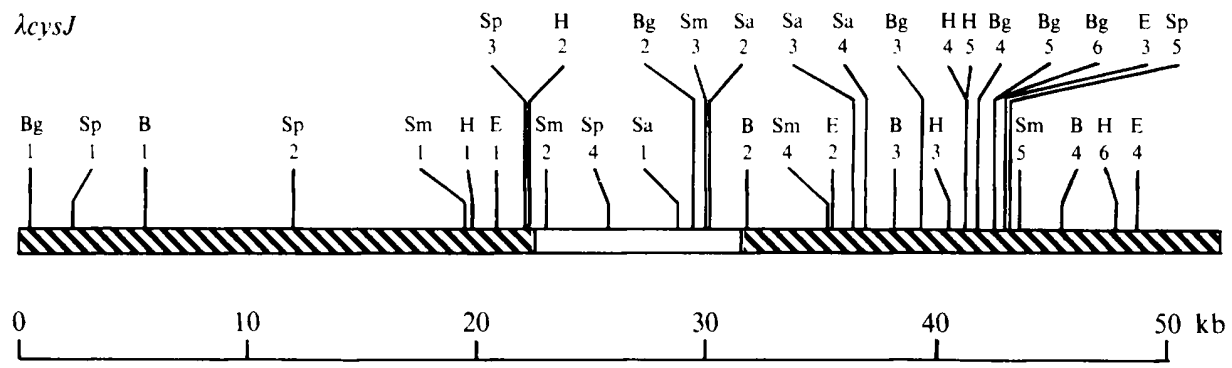

Fig. 3. Locations of restriction sites in $\lambda \mathrm{d} c y s J I H D$ DNA and $\lambda c y s J$ DNA. Restriction site designations : B, BamHI; Bg, BglII; E, EcoRI; H, HindIII; Sa, Sall; Sm, SmaI; Sp, SphI. No site was found for SacI or $X b a \mathrm{I}$ in $\lambda c y s J$ DNA neither was a site found for $S a c \mathrm{I}, S a l \mathrm{I}$ or $\mathrm{XbaI}$ in $\lambda \mathrm{d} c y s J I H D$ DNA. The open box represents bacterial DNA and the shaded box $\lambda$ DNA. The predicted orientation of the cys genes in $\lambda \mathrm{d} c y s J I H D$ DNA is shown below the map. The cys genes are not drawn to scale.

corresponding to $\mathrm{F}$ was detected in only three of the 20 heteroduplex molecules measured. In these three molecules, the length $F$ may well be due to overlapping of the end of the single stranded loop and part of the double stranded DNA. The total of the single stranded deletion loops was used as an internal standard to gain an estimate of about $8 \mathrm{~kb}$ for the size of the bacterial insertion loop. 


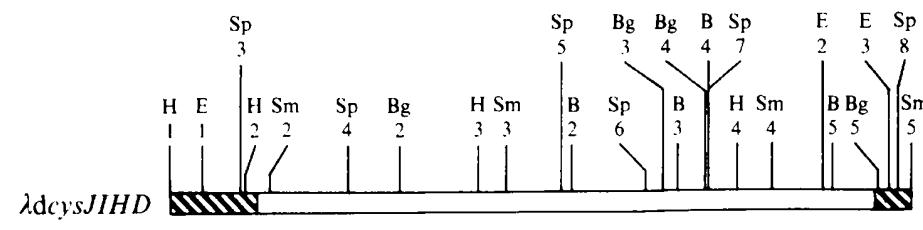

Transforms

$\lambda \mathrm{d} c y s J I H D$

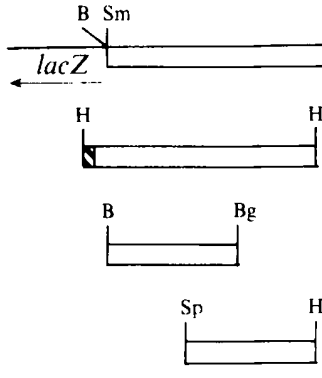

(pMCl403)

to $\mathrm{Cys}^{+}$

pRL9

pRL81

(pLG400)

J H

pRL98

(pBR322)

J H

pRL99

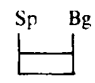

(pBR322)

$J$

pRL100

(pBR322)

$J$

pRL5

(pMC1403)

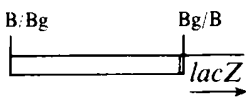

D

pRL6

(pLG400)

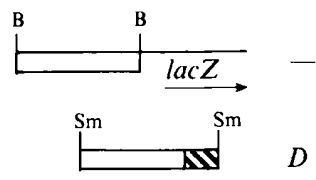

pRL7

(pMC1403)

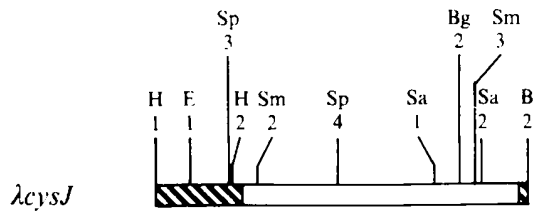

pRLI

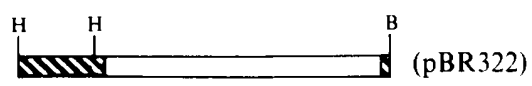

$J$

pRL3

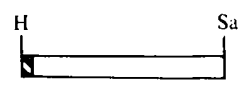

(pBR322)

$J$

$\begin{array}{lcccc}0 & 5 & 10 & 15 & 20 \mathrm{~kb} \\ & 1 & 1 & 1 & 1\end{array}$

Fig. 4. Clones derived from $\lambda \mathrm{d} c y s J I H D$ or $\lambda c y s J$ DNA. The bacterial DNA of each phage is shown with nearby $\lambda$ sequences. Underneath each is shown the insert fragment for each clone. The open box represents bacterial DNA, the shaded box $\lambda$ DNA and the line vector DNA. Restriction site designations are the same as shown in Fig. 3. Where the orientation of the insert with respect to the vector is unknown or where pBR322 was the vector used, the vector line is not shown. The arrows below the lac $Z$ gene indicate the direction of transcription needed for expression. The name of the vector used in the construction of each clone is shown in parentheses. To the right is shown the letter designation of the cys mutation where the plasmid transforms that mutant to $\mathrm{Cys}^{+}$. - represents no $\mathrm{Cys}^{+}$ transformants detected.

\section{Restriction mapping and cloning}

DNA from two transducing phages, $\lambda \mathrm{d} c y s J I H D$ and $\lambda c y s J$, which each carry the cys $J$ gene, was mapped for the sites for several restriction endonucleases. From the left end of the bacterial DNA present in each phage, the first two sites were found to be in equivalent positions, namely $S m a$ I site 2 and $S p h \mathrm{I}$ site 4 . The third site in $\lambda \mathrm{d} c y s J I H D$ DNA, namely $B g / \mathrm{II}$ site 2, was not found in $\lambda$ cys $J$ DNA (see Fig. 3). From that site to the right end of the bacterial DNA in each phage the sites do not correspond. 
Table 3. Cysteine regulation of gene expression

\begin{tabular}{|c|c|c|c|c|c|c|}
\hline \multirow[b]{2}{*}{ Strain } & \multirow[b]{2}{*}{$\begin{array}{l}\text { Relevant } \\
\text { chromosomal } \\
\text { mutation }\end{array}$} & \multirow[b]{2}{*}{ Plasmid } & \multirow[b]{2}{*}{$\begin{array}{c}\text { Gene } \\
\text { product } \\
\text { assayed }\end{array}$} & \multicolumn{2}{|c|}{$\begin{array}{l}\text { Specific activity* for } \\
\text { cells grown on: }\end{array}$} & \multirow[b]{2}{*}{$\begin{array}{l}\text { Derepression } \\
\text { ratio } f\end{array}$} \\
\hline & & & & $\overbrace{\substack{\text { Denkolic acid } \\
(0.42 \mathrm{mM})}}$ & $\begin{array}{l}\text { Cystine } \\
(0.42 \mathrm{~mm})\end{array}$ & \\
\hline RL367 & cys $J$ & pRL9 & cysJ & 4700 & 69 & 68 \\
\hline RL421 & cysJ & - & cysJ & 0 & 0 & $\ldots$ \\
\hline RL622 & cysD & pRL5 & $c y s D$ & 240 & 0 & $>240$ \\
\hline RL432 & cys $D$ & $\ldots$ & $\operatorname{cys} D$ & 0 & 0 & - \\
\hline RL363 & & pRL5 & $\operatorname{lac} Z$ & 430 & 240 & $1 \cdot 8$ \\
\hline RL364 & $\operatorname{lac} Z \Delta m 5265$ & pRL6 & $\operatorname{lac} Z$ & 3450 & 11 & 310 \\
\hline RL365 & & pRL 7 & $\operatorname{lac} Z$ & 49 & 5 & 10 \\
\hline RL367 & & pRL9 & $\operatorname{lac} Z$ & 910 & 80 & 11 \\
\hline RL421 & & - & $\operatorname{lac} Z$ & 5 & 4 & 1 \\
\hline MC4100 & $\Delta l a c U 169$ & - & $\operatorname{lac} Z$ & 0 & 0 & - \\
\hline
\end{tabular}

* cysJ: NADPH-cytochrome $c$ reductase. Specific activity given as nmol cytochrome $c$ reduced $\mathrm{min}^{-1}$ (mg protein) ${ }^{-1}$. cys D: ATP sulphurylase. Specific activity given as nmol 3'-phospho-5'-adenyl sulphate (PAPS) produced $\mathrm{h}^{-1}$ (mg protein $)^{-1}$. lacZ: units as defined by Miller (1972).

$\uparrow$ Ratio of specific activity for cells grown on djenkolic acid to that for cells grown on cystine.

To locate some of the genes on the bacterial DNA carried by $\lambda \mathrm{d}$ cysJIHD or $\lambda$ cysJ, various fragments were cloned into the fusion vectors pLG400 and pMC1403 as well as into pBR322. The two fusion vectors were chosen in an attempt to detect cysteine regulated promoters. Such detection would only be possible if the bacterial DNA was inserted in the correct orientation, if the insert carried a translational initiation signal and if the reading frame on the insert matched that of the lac I-lac $Z$ coding sequences of pLG 400 or of the lac $Z$ coding region of pMC1403. The fragments and vectors used in these constructions are listed in Table 2.

As pRL98 and pRL99 both transform a cysJ strain to Cys ${ }^{+}$(Fig. 4), this suggests that the cys $J$ gene is located on DNA common to the inserts in these two plasmids, namely from $S p h I$ site 4 to $B g l$ II site 2 in $\lambda \mathrm{d} c y s J I H D$ DNA. That the cysJ gene is present between these sites was confirmed by the ability of pRL100 to transform a cys $J$ strain to Cys ${ }^{+}$(Fig. 4). The cys $J$ gene is present in the insert of pRL3: the insert of pRL3 therefore has DNA common to pRL100. Since pRL81 can transform a $c y s H$ strain to $\mathrm{Cys}^{+}$, the $c y s H$ gene must lie to the left of the HindIII site 3 in $\lambda \mathrm{d} c y s J I H D$ DNA. pRL5 and pRL7 transform a cysD strain to Cys ${ }^{+}$. Thus the $c y s D$ gene is located between $S m a$ I site 4 and the novel joint at the right end of the bacterial DNA carried by $\lambda \mathrm{d} c y s J I H D$. The failure of $\mathrm{pRL} 6$ to transform a $c y s D$ mutant to $\mathrm{Cys}^{+}$indicates that BamHI site 5 lies within the cys $D$ gene.

In order to test whether some constructs carried a complete copy of the cysJ gene or the cys $D$ gene, assays for the enzymes encoded by these genes were done. To further test for cysteine regulation of expression, the assays were done for cells grown on cysteine, which leads to a low or repressed enzyme level, or on djenkolic acid, a poor sulphur source, which leads to a high or derepressed enzyme level. The derepression ratio (derepressed level/repressed level) provides an index of cysteine regulation. For inserts in the fusion vectors pLG400 and pMC1403, $\beta$ galactosidase assays were done on cells grown under both conditions. Demonstration of cysteine regulation of $\beta$-galactosidase would enable the direction of transcription from the cysteine regulated promoter on the insert to be deduced.

The derepression ratios for certain plasmids are shown in Table 3. pRL9 has NADPHcytochrome $c$ reductase under cysteine control. Thus the $c y s J$ gene and its promoter are located within the insert carried by pRL9 but the degree of cysteine control of $\beta$-galactosidase is in comparison much lower. Likewise, the cysteine regulation of ATP sulphurylase from pRL5 shows that the cys $D$ gene and its promoter are present in the insert. By contrast, the regulation by cysteine of $\beta$-galactosidase was insignificant when compared to the ATP sulphurylase results. Only for pRL6 is $\beta$-galactosidase clearly regulated by a cysteine controlled promoter. 


\section{DISCUSSION}

The size of $9.9 \mathrm{~kb}$ for the double stranded region of the heteroduplex molecules with $\lambda \mathrm{d}$ cys JIHD to the right of the attachment site $(\mathrm{H})$ corresponds to the loss of $\lambda$ DNA on formation of $\lambda \mathrm{dcysJIHD}$ from the $\lambda$ map coordinates of $27731 \mathrm{bp}(\mathrm{att})$ to about $38600 \mathrm{bp}$. The secondary site lysogen which yielded $\lambda \mathrm{d} c y s J I H D$ was a $\mathrm{Cys}^{+}$strain. Thus the prophage in this strain is not located in a cys gene. Since $\lambda \mathrm{d} c y s J i H D$ transduces to $\mathrm{Cys}^{+}$mutants having mutations in the $c y s J$, $I, H$ and $D$ genes but not the cysC gene then the prophage in the secondary site lysogen must be located near the cysJ gene end of the cluster but beyond the cluster. Thus the cys genes on $\lambda \mathrm{d} c y s J I H D$ must be oriented as shown in Fig. 3. The determination of $\lambda \mathrm{d} c y s J I H D$ as being a biotype transducing phage establishes the orientation of the prophage in the secondary site lysogen which yielded $\lambda \mathrm{d}$ cys $J I H D$ (strain RL75) as: $N$ gene of $\lambda-J$ gene of $\lambda-c y s J-c y s I-c y s H-c y s D$.

The $\lambda$ DNA lost on formation of $\lambda \mathrm{d} c y s J I H D$ probably corresponds to the loss of the $N$ and $c I$ genes. The fact that the phage is defective is consistent with the loss of gene $N$.

The heteroduplex molecules observed with $\lambda \mathrm{d} c y s J I H D$ and $\lambda c y s J$ DNA had no deletion loops corresponding to the expected nin5 deletion. That the $5804 \mathrm{bp} E c o$ RI fragment and the $6527 \mathrm{bp}$ $B a m \mathrm{HI}$ fragment of $\lambda$ DNA were present in the respective digests of $\lambda \mathrm{d} c y s J I H D$ and $\lambda c y s J$ DNA confirms that the nin 5 deletion (from 40.6 to $43.4 \mathrm{~kb}$ of $\lambda$ DNA, Szybalski \& Szybalski, 1979) is not present in each transducing phage DNA.

For $\lambda c y s J$ DNA, both heteroduplex analysis and restriction enzyme analysis are consistent with the loss of no or very little $\lambda$ DNA due to the bacterial DNA insertion. If none has been lost then the bacterial DNA may be derived from the two regions of the chromosome which are adjacent to the two ends of the prophage in the secondary site lysogen. Transducing phage of this type have been reported by Britton et al. (1983). If this is so then the novel joint between these two regions of bacterial DNA should be located to the left of the position in $\lambda c y s J$ which is aligned with the $B g /$ II site 2 in $\lambda \mathrm{d} c y s J I H D$ DNA as depicted in Fig. 3. Another possibility is that during the excision event on formation of $\lambda c y s J$ other recombination and deletion events have occurred such as reported by Jorgensen et al. (1978).

From the restriction enzyme analysis, $\lambda c y s J$ has a length of $52.1 \pm 1.3 \mathrm{~kb}$ and $\lambda \mathrm{d} c y s J I H D$ has a length of $51.8 \pm 0.7 \mathrm{~kb}$. Thus they are both close to $107 \%$ of wild-type length. Feiss et al. (1977) have observed packaging recoveries of $100 \%$ for phage genomes which are $105 \%$ of wild-type length but $20 \%$ for genomes of $109 \%$ of wild-type length.

The location by cloning experiments of the $c y s J$ and $c y s D$ genes in $\lambda \mathrm{d} c y s J I H D$ DNA (see Fig. 4) confirms the predicted orientation of the gene cluster carried by this phage shown in Fig. 3. From the order of genes of the cluster derived by Jones-Mortimer (1973), the $c y s H$ gene must lie between the cys $J$ and cys $D$ genes, i.e. to the right of the $c y s J$ gene, and from cloning experiments reported here (Fig. 4) it lies to the left of HindIII site 3 at coordinate $26.90(\mathrm{~kb})$. Since the cysD gene is located to the right of SmaI site 4 at coordinate 38.88 , there is a large 'silent section' of DNA of at least $11 \mathrm{~kb}$ in which no known cysteine genes are located. This is the first evidence for the physical size of this region in either E. coli K12 or $S$. typhimurium. Previously the term 'silent section' has been used for the section between the cysH and cys $D$ genes of $S$. typhimurium which was estimated to be about as long as the remainder of the cluster from recombination frequency data (Demerec et al., 1963).

One of the conditions for $\beta$-galactosidase to be expressed on cloning fragments into pLG400 or pMC1403 is that the insert must contain a promoter in the correct orientation. The direction of transcription of the $c y s J$ gene is unknown. If it is transcribed from left to right in $\lambda \mathrm{d} c y s J I H D$ DNA (as depicted in Fig. 3) then the insert in pRL9 is in the wrong orientation for expression of lac $Z$ from this promoter. This could be the reason that a comparatively low level of cysteine control of $\operatorname{lac} Z$ was observed.

The cysteine control of $\beta$-galactosidase demonstrated for pRL6 and the mapping of the orientation of the insert establish that the cysteine regulated promoter on the insert directs transcription from left to right with respect to $\lambda \mathrm{d} c y s J I H D$ DNA. Since the insert of pRL7 contains the cysD gene (see Fig. 4) and the BamHI site 5 is within the gene (see Results) the promoter detected on pRL6 must be that for the cysD gene. This establishes the orientation of the cys $D$ gene on $\lambda \mathrm{d} c y s J I H D$ DNA and from this the orientation on the $E$. coli chromosome is 
such that it is transcribed anticlockwise with respect to the linkage map (Bachmann, 1983). For pRL5 the cysD gene promoter is present in the correct orientation but no control of lac $Z$ expression by cysteine was observed. The complete $c y s D$ gene is present as judged from the ATP sulphurylase results and it is not clear whether another reading frame under cysteine control would be fused to lac $Z$. The reason for the level of $\beta$-galactosidase observed for cells grown in the presence of cystine is unknown.

R. M. Whalley and G. D. Clark-Walker are thanked for their helpful advice and R. Czolij, S. Johnstone and D. Francis are thanked for their invaluable assistance. The use of computing facilities at Pittmen Data Systems Pty Ltd, Sydney, and those provided by C. D. Shorey are gratefully appreciated. This work was funded by an ARGS grant.

\section{REFERENCES}

BACHMANN, B. J. (1983). Linkage map of Escherichia coli K-12, edition 7. Microbiological Reviews 47, 180230.

Britton, P., Boronat, A., Hartley, D. A., JonesMortimer, M. C., Kornberg, H. L. \& Parra, F. (1983). Phosphotransferase-mediated regulation of carbohydrate utilization in Escherichia coli K12: location of the gsr (tgs) and iex (crr) genes by specialized transduction. Journal of General Microbiology 129, 349-358.

Casadaban, M. J. (1976). Transposition and fusion of the lac genes to selected promoters in Escherichia coli using bacteriophage lambda and Mu. Journal of Molecular Biology 104, 541-555.

Casadaban, M. J., Chou, J. \& Cohen, S. N. (1980). In vitro gene fusions that join an enzymatically active $\beta$-galactosidase segment to amino-terminal fragments of exogenous proteins: Escherichia coli plasmid vectors for the detection and cloning of translational initiation signals. Journal of Bacterio$\log y$ 143, 971-980

Cohen, S. N., Chang, A. Y. C. \& Hsu, L. (1972). Nonchromosomal antibiotic resistance in bacteria: genetic transformation of Escherichia coli by R-factor DNA. Proceedings of the National Academy of Sciences of the United States of America 69, 21102114.

Davis, R. W. \& Parkinson, J. S. (1971). Deletion mutants of bacteriophage lambda. III. Physical structure of att ${ }^{\Phi}$. Journal of Molecular Biology 56, 403-423.

Davis, R. W., Simon, M. \& Davidson, N. (1971). Electron microscope heteroduplex methods for mapping regions of base sequence homology in nucleic acids. Methods in Enzymology 21, 413-428.

Davis, R. W., Botstein, D. \& Roth, J. R. (1980). $A$ Manual for Genetic Engineering. Advanced Bacterial Genetics. Cold Spring Harbor, NY: Cold Spring Harbor Laboratory.

Demerec, M., Gillespie, D. H. \& Mizobuchi, K. (1963). Genetic structure of the cysC region of the Salmonella genome. Genetics 48, 997-1009.

Feiss, M., Fisher, R. A., Crayton, M. A. \& Egner, C. (1977). Packaging of the bacteriophage $\lambda$ chromosome: effect of chromosome length. Virology 77, 281-293.

Fimmel, A. L. \& Loughlin, R. E. (1977). Isolation of a $\lambda$ dcys transducing bacteriophage and its use in determining the regulation of cysteine messenger ribonucleic acid synthesis in Escherichia coli $\mathrm{K}-12$. Journal of Bacteriology 132, 757 -763.
GotTesman, M. E. \& Yarmolinsky, M. B. (1968). Integration-negative mutants of bacteriophage lambda. Journal of Molecular Biology 31, 487-505.

GREGORY, J. D. (1962). Sulfate-transferring enzymes. I. Phenol sulphokinase. Methods in Enzymology 5, 977-980.

Guarente, L., Lauer, G., Roberts, T. M. \& Ptashne, M. (1980), Improved methods for maximizing expression of a cloned gene: a bacterium that synthesizes rabbit $\beta$-globin. Cell 20, 543-553.

INGLE, C. P. \& Loughlin, R. E. (1980). Isolation and characterization of a $\lambda$ transducing bacteriophage carrying the cysE gene of Escherichia coli K-12. Australian Journal of Biological Sciences 33, 605612.

JONES-MORTIMER, M. C. (1973). Mapping of structural genes for the enzymes of cysteine biosynthesis in Escherichia coli K12 and Salmonella typhimurium LT2. Heredity 31, 213-221.

Jorgensen P., Collins, J., Fill, N. \& von MEYenBURG, K. (1978). A ribosomal RNA gene, $r r n C$, of Escherichia coli, mapped by specialized transducing $\lambda \mathrm{d} i l v$ and $\lambda \mathrm{d} r b s$ phages. Molecular and General Genetics 163, 223-228.

KREDICH, N. M. (1971). Regulation of L-cysteine biosynthesis in Salmonella typhimurium. I. Effects of growth on varying sulfur sources and $O$-acetyl-Lserine on gene expression. Journal of Biological Chemistry 246, 3474-3484.

Lis, J. T. \& Schleif, R. (1975). The isolation and characterization of plaque-forming arabinose transducing bacteriophage $\lambda$. Journal of Molecular Biology 95, 395-407.

LOUGHLIN, R. E. (1975). Polarity of the cysJIH operon of Salmonella typhimurium. Journal of General Microbiology 86, 275-282.

LoughLIN, R. E. (1976). Identification of nonsense mutations in the cysJ gene of Salmonella typhimurium. Journal of General Microbiology 95, 186-187.

Maniatis, T., Fritsch, E. F. \& Sambrook, J. (1982). Molecular Cloning. A Laboratory Manual. Cold Spring Harbor, NY: Cold Spring Harbor Laboratory.

Miller, J. H. (1972). Experiments in Molecular Genetics. Cold Spring Harbor, NY: Cold Spring Harbor Laboratory.

SANDERSON, K. E. \& RoTh, J. R. (1983). Linkage map of Salmonella typhimurium, edition VI. Microbiological Reviews 47, 410-453.

Sanger, F., Coulson, A. R., Hong, G. F., Hill, D. F. \& Petersen, G. B. (1982). Nucleotide sequence of 
bacteriophage $\lambda$ DNA. Journal of Molecular Biology 162, 729-773.

Selker, E., Brown, K. \& Yanofsky, C. (1977). Mitomycin C-induced expression of trpA of Salmonella typhimurium inserted into the plasmid ColE1. Journal of Bacteriology 129, 388-394.

Shimada, K., Weisberg, R. A. \& Gottesman, M. E. (1972). Prophage lambda at unusual chromosomal locations. I. Location of the secondary attachment sites and the properties of the lysogens. Journal of Molecular Biology 63, 483-503.

SIEGEL, L. M. (1975). Biochemistry of the sulfur cycle. In Metabolic Pathways, 3rd edn, vol. 7, pp. 217-286. Edited by D. M. Greenberg. New York: Academic Press.

Silhavy, T. J., Berman, M. L. \& Enquist, L. W. (1984). Experiments with Gene Fusions. Cold Spring Harbor, NY: Cold Spring Harbor Laboratory.

STEEGE, D. A. \& Low, B. (1975). Isolation and characterization of lambda transducing bacteriophages for the sul' $\left(\sup D^{-}\right)$amber suppressor of Escherichia coli. Journal of Bacteriology 122, 120-128. SutCliffe, J. G. (1979). Complete nucleotide sequence of the Escherichia coli plasmid pBR322. Cold Spring Harbor Symposia on Quantitative Biology 43, 77-90.

SZYBALSKI, E. H. \& SzYBaLSKI, W. (1979). A comprehensive molecular map of bacteriophage lambda. Gene 7, 217270 .

Trudinger, P. A. \& Loughlin, R. E. (1981). Metabolism of simple sulphur compounds. In Comprehensive Biochemistry vol. 19A, pp. 165-256. Edited by M. Florkin, E. H. Stotz, A. Neuberger \& L. L. M. van Deenen. Amsterdam: Elsevier/North Holland Biomedical Press.

UMBARGER, H. E. (1978). Amino acid biosynthesis and its regulation. Annual Review of Biochemistry 47, 533606. 